\title{
Pengembangan Media Interaktif Augmented Reality Berbasis Android Dalam Pengenalan Jenis Minuman Kopi
}

\author{
Edwin Meinardi Trianto ${ }^{1 *}$, Novi Tri Hariyanti \\ ${ }^{1,2}$ Program Studi Manajemen Informatika, Institut Informatika Indonesia, Surabaya, Jawa Timur \\ Email: ${ }^{*}$ edwin@ikado.ac.id, ${ }^{2}$ novi@ikado.ac.id
}

(Naskah masuk: 28 Sep 2020, direvisi: 13 Okt 2020, diterima: 14 Okt 2020)

\begin{abstract}
Abstrak
Kopi merupakan salah satu minuman yang paling sering dikonsumsi di seluruh dunia. Kopi dapat dinikmati dengan banyak cara penyeduhan dan penambahan elemen lainnya, yang dapat menghasilkan cita rasa yang berbeda. Tumbuh pesatnya jumlah penikmat kopi baru tanpa disertai edukasi menyeluruh tentang varian rasa kopi membuat hanya sedikit penikmat kopi yang dapat mengenal dan mengapresiasi rasa kopi dengan cara yang berbeda. Media interaktif dirancang untuk mengenalkan banyak varian minuman kopi pada masyarakat. Untuk meningkatkan keterlibatan pengguna media interaktif, diterapkan teknologi Augmented Reality untuk memvisualisasikan pengenalan varian kopi. Hal ini dilakukan untuk memberikan gambaran jelas terhadap jenis varian kopi agar mempermudah pengguna memahami informasi diberikan serta memberikan pengalaman visual learning yang lebih dalam. Aplikasi media interaktif ini memanfaatkan smartphone berbasis Android yang dikembangkan menggunakan Unity 3D dan Vuforia Qualcomm Augmented Reality Software Development Kit, serta menggunakan Unified Modeling Language (UML) untuk membantu analisis pengembangan sistem. Pengujian dilakukan dengan metode black box testing dan kuisioner yang menyimpulkan bahwa aplikasi Coffee AR ini dapat membantu mengenalkan varian menu minuman kopi secara interaktif. Hal ini dibuktikan dari hasil 30 responden yang menggunakan aplikasi Coffee AR.
\end{abstract}

Kata Kunci: Augmented Reality, Media Interaktif, Kopi, Unity, Vuforia.

\section{Development of Android-Based Augmented Reality Interactive Media Application in Introduction to Types of Coffee Drinks}

\begin{abstract}
Coffee is one of the most consumed drinks worldwide. Coffee can be enjoyed in many ways, by brewing or even adding other elements, which can produce another different flavor. The rapid growth in the number of new coffee drinkers without proper education into coffee and its flavor variants has made only a few coffee drinkers able to enjoy and appreciate the taste of coffee in a different way. This Interactive media is designed to introduce many variants of coffee drinks to the public. To gaining involvement of interactive media users, Augmented Reality technology was applied to visualize the introduction of coffee variants. The purpose of this interactive media is to giving deeper visual learning experiences about types of coffee variants, in order to make it easier for users to understand the provided information. This interactive media application utilizes an Androidbased smartphone and developed using Unity 3D and the Vuforia Qualcomm Augmented Reality Software Development Kit, and using the Unified Modeling Language (UML) to help analyze system development. Tests were carried out using the black box testing method and a questionnaire, and the results are concluded that the Coffee AR application could help introduce coffee drink menu variants interactively. This is proved by 30 respondents' reaction after using the Coffee AR application.
\end{abstract}

Keywords: Augmented Reality, Interactive Media, Coffee, Unity, Vuforia. 


\section{PENDAHULUAN}

Kopi merupakan minuman yang paling sering dikonsumsi di dunia. Meminum kopi telah dikenal dan dilakukan sejak dulu sehingga lahirnya budaya minum kopi diberbagai macam tempat hingga sekarang. Karena minuman kopi telah diadaptasi menjadi budaya, maka cara mengkonsumsi kopi juga mengalami perubahan sesuai dengan gaya hidup setempat. Penggunaan susu, jumlah takaran air, maupun penambahan rasa lain yang membuat minuman kopi menjadi unik dan dapat menyesuaikan selera masing-masing orang. Maka dari itu, terdapat berbagai macam varian minuman kopi yang muncul dari berbagai belahan dunia.

Masyarakat Indonesia telah mengenal kopi dan memiliki budaya mengkonsumsi kopi sejak dulu. Hingga kini, kebudayaan mengkonsumsi kopi juga dilakukan dan makin populer semenjak meminum kopi dikaitkan dengan produktivitas. Munculah berbagai macam kedai kopi dimana masyarakat dapat mengkonsumsi minuman kopi dengan berbagai varian jenis minuman kopi yang telah disajikan oleh masing-masing kedai tersebut. Kebanyakan pada kedai kopi memiliki menu yang serupa, sehingga masyarakat hanya mengetahui beberapa jenis minuman kopi saja, seperti cappuccino, latte, dan black coffee meskipun masih terdapat banyak varian minuman kopi yang lainnya. Saat memilih menu minuman kopi, seringkali masyarakat awam kebingungan dengan istilah-istilah asing yang muncul pada menu toko kopi. Dalam konteks varian minuman kopi, konsumen yang awam masih memiliki pandangan bahwa jenis minuman kopi hanya dicampur susu atau air saja.

Indonesia merupakan salah satu produsen penghasil kopi terbesar di dunia. Banyak varian biji kopi yang dihasilkan di Indonesia, seperti Kopi Gayo dari Aceh, Sumatra yang cukup terkenal bisa dinikmati dalam berbagai varian penyajian kopi. Karena keterbatasan pengetahuan masyarakat terhadap jenis minuman kopi, sehingga tidak banyak masyarakat yang dapat menikmati keunikan dari rasa kopi tersebut. Dengan cara seduh dan penyajian yang berbeda, bubuk kopi bisa menghasilkan rasa yang berbeda pula. Oleh sebab itu, diperlukan pengetahuan lebih dalam terhadap jenis varian minuman kopi agar dapat menikmati kopi dengan cara yang berbeda, mengingat banyaknya cara untuk mendapatkan rasa berbeda dari penyeduhan serta penyajian kopi.

Untuk mengedukasi masyarakat terhadap jenis varian minuman kopi, dirancanglah media interaktif yang bersifat informatif. Penelitian ini ditujukan bagi masyarakat awam yang belum mengetahui varian minuman kopi secara menyeluruh. Media interaktif dibuat dengan menggunakan teknologi Augmented Reality untuk memvisualisasikan informasi yang mudah diterima bagi penggunanya. Dengan adanya media interaktif ini, masyarakat diharapkan akan lebih mengapresiasi minuman kopi dan dapat menikmatinya dengan cara berbeda.

Terdapat berbagai media interaktif yang berfokus pada media pembelajaran, salah satunya menggunakan media interaktif Augmented Reality. Dengan adanya teknologi ini, terdapat manfaat khususnya perihal komunikasi pendidikan terutama proses pembelajaran [1]. Teknologi Augmented
Reality pun dapat digunakan sebagai media edukasi permainan dan pembelajaran salah satu permainan papan di dunia [2]. Dari berbagai media komunikasi, media interaktif dalam penggunaan teknologi Augmented Reality memungkinkan dalam hal penyampaian informasi mendalam, sehingga pengguna mendapatkan pengetahuan visual dengan lebih baik.

\section{METODOLOGI PENELITIAN}

\section{A. Augmented Reality}

Augmented Reality adalah suatu media perantara antara manusia dengan komputer, manusia dengan manusia, dan komputer dengan manusia [3]. Secara garis besar, Augmented Reality dapat dikatakan visualisasi objek benda yang nyata maupun maya secara terintegrasi yang ditampilkan pada lingkungan yang riil, berjalan dalam zona waktu nyata secara interaktif. Karekteristik yang dimiliki oleh Augmented Reality adalah sebagai berikut:

1. Menggabungkan lingkungan nyata dan virtual.

2. Berjalan secara interaktif dalam waktu nyata.

3. Berintegrasi dalam tiga dimensi (3D).

Pembelajaran dengan teknologi Augmented Reality bertujuan untuk mengambil dunia nyata sebagai dasar dengan menggabungkan beberapa teknologi virtual dan menambahkan data kontekstual untuk pengalaman pembelajaran yang lebih baik [4], dikarenakan penggunanya dapat melihat secara langsung penggambaran virtual secara nyata. Penggunaan Augmented Reality dibutuhkan untuk menarik keingintahuan manusia terutama dibidang visualisasi. Dengan objek 3D yang dimunculkan dalam media, user dapat lebih menangkap dan dengan mudah membayangkan informasi yang diberikan, sehingga menimbulkan pengalaman interaksi yang berbeda.

\section{B. Minuman Kopi}

Kopi terbuat dari gilingan biji kopi yang telah disangrai dan kemudian disajikan dengan cara seduh. Kopi dikenal sebagai salah satu komoditas dunia yang sering diperdagangkan serta dibudidayakan lebih dari 50 negara [5]. Ada 2 varian biji kopi yang sering dijumpai, yakni arabika yang kaya akan rasa dan robusta yang memiliki rasa lebih kuat serta cenderung pahit. Banyak orang percaya pada mitos bahwa semakin gelap kopi semakin kuat, hal inilah yang membuat penyeduhan kopi bisa memiliki banyak kriteria [6]. Karena kopi merupakan minuman yang populer dikalangan masyarakat, maka muncullah berbagai macam penyeduhan kopi serta penyajian yang berbeda dan unik. Ada beberapa macam jenis menu penyajian kopi yang dapat diterapkan, seperti:

1. Espresso Based

2. Espresso dengan susu

3. Kopi dengan susu

4. Espresso atau kopi dengan whipped cream

5. Espresso dengan kopi

6. Kopi dengan teh

7. Kopi dengan alkohol

8. Kopi dengan air karbonasi

9. Kopi disajikan dengan rempah-rempah

10. Kopi dengan campuran rasa 
11. Kopi yang disajikan dingin

12. Lainnya

\section{Vuforia Qualcomm}

Vuforia Qualcomm berperan sebagai library yang digunakan sebagai pendukung pembuatan Augmented Reality (AR) dalam sistem operasi Android dan IOS [7]. Salah satu cara kerja Vuforia adalah dengan mendeteksi gambar atau disebut dengan marker untuk menampilkan objek Augmented dengan menggunakan perangkat kamera pada smartphone. Objek Augmented tersebutlah yang menjadi olahan informasi bagi penggunanya. Vuforia memiliki keunggulan yang dapat membantu pengembang dalam untuk mendesain dan membuat aplikasi dengan teknologi AR, yakni:

1. Kemampuan Tracking dan Detection marker yang cepat.

2. Teknologi computer vision unggulan yang mampu menampilkan efek khusus pada mobile device.

3. Mampu mendeteksi gambar lebih dari satu secara mudah.

4. Pengaturan database yang mudah dan fleksibel.

\section{Unity 3D}

Unity merupakan perangkat lunak untuk mengembangkan aplikasi yang berfokus pada permainan atau game berbasis 2D maupun 3D [8]. Unity Technologies dibangun pada tahun 2004 oleh David Helgason (CEO), Nicholas Francis (CCO), dan Joachim Ante (CTO) di Copenhagen, Denmark. Unity memiliki beberapa fitur yang dibutuhkan dalam pembuatan aplikasi seperti Rendering, Scripting, Asset Tracking, Platforms, Asset Store serta Physics. Karena fitur-fitur yang mendukung kemudahan pembuatan aplikasi khususnya di bidang game, para pengembang perangkat sering menggunakan sistem Unity 3D. Aplikasi yang dirancang melalui Unity 3D dapat dipublikasikan dengan mudah ke berbagai platform sistem operasi.

\section{E. Statistical Package for the Social Sciences (SPSS)}

Statistical Package for the Social Sciences (SPSS) adalah perangkat lunak yang digunakan untuk pendataan dibidang statistik dan menganalisis data yang telah dikumpulkan [9]. Data olahan SPSS memberikan kemudahan bagi pengguna untuk mengolah informasi secara detil.

\section{HASIL PEMBAHASAN}

\section{A. Analisis Permasalahan}

Dengan perkembangan industri yang berfokus pada bahan baku kopi, baik industri yang memanen varian biji kopi dengan keunikan rasanya, maupun yang memproduksi minuman kopi dengan berbagai ragam kombinasi, tidak diimbangi dengan edukasi kepada masyarakat tentang jenis maupun ragam minuman kopi yang bisa didapatkan. Sayangnya, Indonesia tidak termasuk 10 besar peminum kopi terbesar di dunia. Padahal, Indonesia sendiri dikenal sebagai salah satu penghasil dan eksportir kopi terbesar dunia. Karena kurangnya pengetahuan mendalam tentang kopi terhadap masyarakat, maka akan menimbulkan ketidakpahaman konsumen awam tentang kayanya ragam minuman kopi.
Permasalahan yang muncul saat memperkenalkan varian kopi kepada masyarakat adalah:

- Pengetahuan yang kurang mendalam pada masyarakat tentang ragam dan jenis varian minuman kopi, sehingga hanya memilih varian kopi pada rentang yang terbatas.

- Istilah-istilah asing pada menu kopi yang digunakan ditempat-tempat penjualan minuman kopi

- Apresiasi yang kurang dari masyarakat Indonesia terhadap varian minuman kopi lainnya.

Dari permasalahan yang timbul di atas dapat ditarik kesimpulan edukasi tentang varian jenis kopi perlu dilakukan. Dengan menggunakan aplikasi Coffee AR, masyarakat awam mendapatkan banyak kemudahan dan informasi dalam menjelaskan macam varian minuman kopi yang ada. Selain itu, dengan menggunakan informasi pembuatan pada video serta objek 3D yang menggambarkan rasio pembuatan jenis kopi, konsumen dapat lebih cepat memahami tentang varian kopi tersebut.

\section{B. Desain Sistem}

Pengembangan media interaktif ini dibutuhkan analisis tentang rancangan dan alur sistem. Analisis sistem ini akan dipermudah dengan pembagian analisis dengan berbagai segmen. Pada setiap segmen analisis akan dijelaskan mengenai Unified Modeling Language (UML) yang terdiri dari use case diagram beserta detil scenario dari masingmasing use case, activity diagram, dan sequence diagram yang membantu pengembangan sistem.

\section{Use Case Diagram}

Use case diagram merupakan salah cara pemodelan sistem yang menggunakan konsep OOP (Object Oriented Programming). Use case diagram dapat memvisualisasi fungsi dari sistem yang akan berinteraksi atau berjalan dengan faktor eksternal atau yang kita kenal dengan pengguna. Setiap use case terdapat skenario yang menggambarkan alur proses yang berhubungan dengan pengguna. Berikut dijabarkan use case diagram pada aplikasi ini.

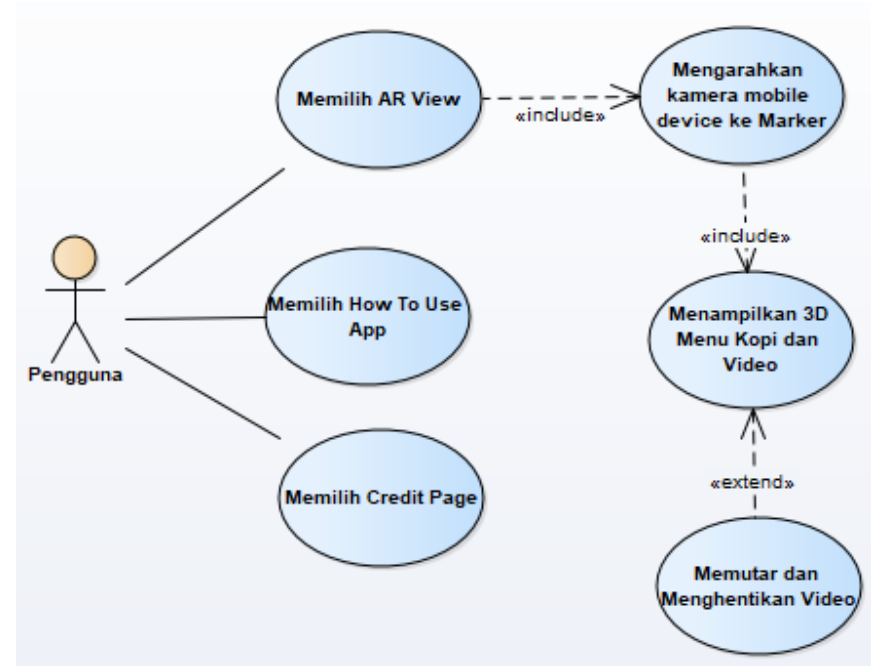

Gambar 1. Use Case Diagram Aplikasi Coffee AR 
Pada Gambar 1 menunjukan sistem ini memiliki 1 aktor yang disebut dengan pengguna. Pengguna ini dapat berinteraksi dengan 3 menu awal, yaitu AR View, How To Use App, Credit Page. Jika pengguna memilih menu AR View maka secara otomatis kamera device akan menyala dan pengguna bisa memidai marker yang ada. Jika marker sesuai dengan yang terdaftar pada sistem, maka objek 3D dan video yang sesuai akan tampil. Disamping itu pengguna dapat melihat menu Credit Page untuk melihat nama dari orang yang berkontribusi untuk pengembangan sistem ini dan menu How to Use App untuk melihat keterangan bagaimana cara menggunakan apikasi Coffee AR.

\section{Activity Diagram}

Activity diagram merupakan salah satu cara untuk memodelkan sistem dengan merepresentasikan workflow dari interaksi kegiatan serta memiliki pilihan kegiatan, pengulangan, dan concurrency. Diagram ini dapat menggambarkan langkah secara detail urutan aktivitas dalam sebuah proses. Dengan adanya activity diagram maka dapat membantu memahami proses sistem secara keseluruhan. Berikut akan dijabarkan activity diagram yang mengacu pada use case yang sudah dirancang:

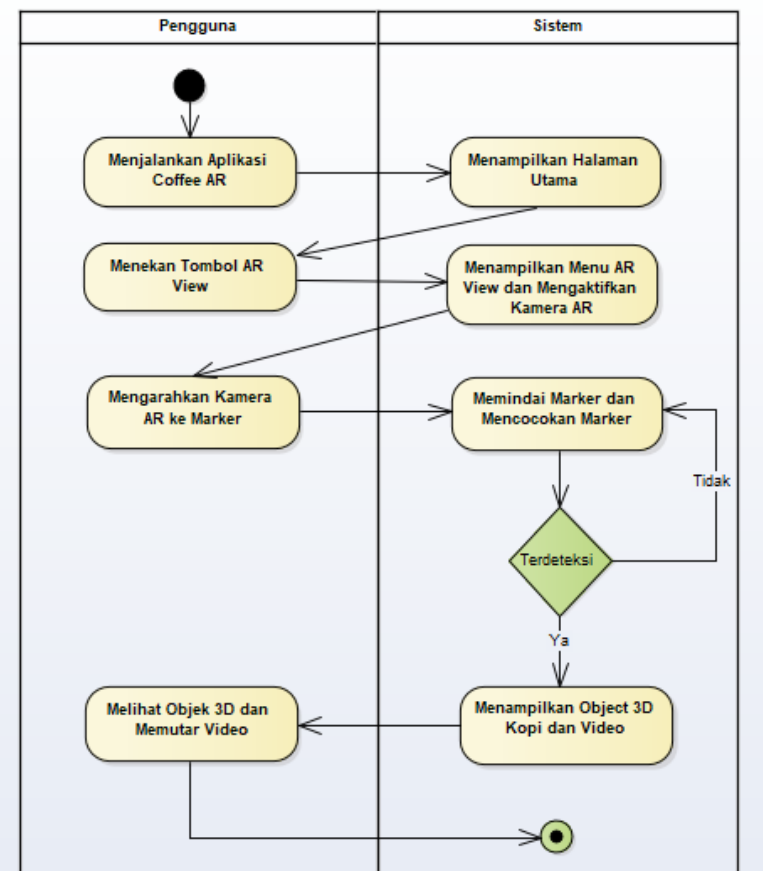

Gambar 2. Activity Diagram Memilih Menu AR View Untuk Menampilkan Objek 3D dan Video

Pada Gambar 2 pengguna memulai aplikasi Coffee AR dan sistem menampilkan halaman utama. Pengguna dapat menekan tombol AR View untuk membuka menu AR View dan secara otomatis sistem mengaktifkan kamera pada mobile. Jika kamera mengarah ke marker yang sudah terdaftar pada data Vuforia, maka sistem akan mencocokan dan jika benar, maka sistem akan menampilkan objek 3D dan video. Pengguna dapat melihat objek 3D dan berinteraksi dengan video yang muncul.

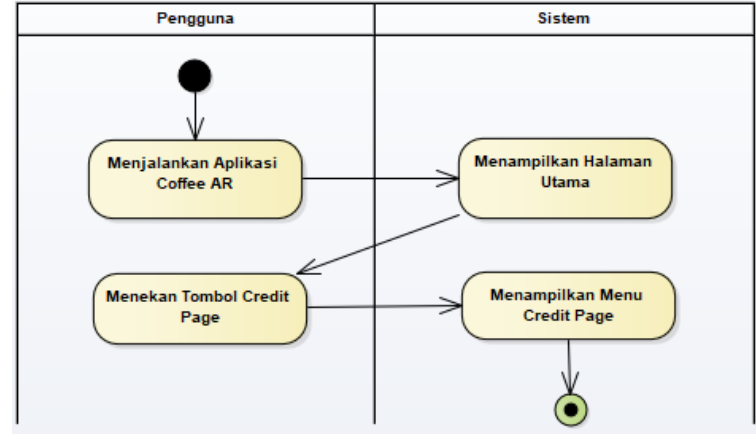

Gambar 3. Activity Diagram Memilih Credit Page

Pada Gambar 3 pengguna dapat membuka aplikasi dan sistem akan menampilkan halaman utama. Kemudian pengguna dapat menekan tombol Credit Page untuk melihat nama-nama yang berkontribusi. Setelah pengguna menekan tombol Credit Page, maka sistem akan menampilkan menu Credit Page.

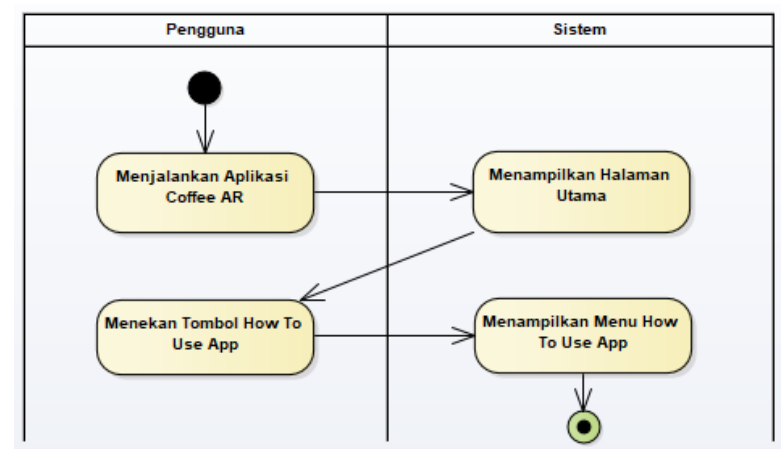

Gambar 4. Activity Diagram Memilih How To Use App

Pada Gambar 4 pengguna dapat membuka aplikasi dan sistem akan menampilkan halaman utama. Kemudian pengguna dapat menekan tombol How To Use App untuk mengetahui cara penggunakan aplikasi. Setelah pengguna menekan tombol How To Use App, maka sistem akan menampilkan menu How To Use App.

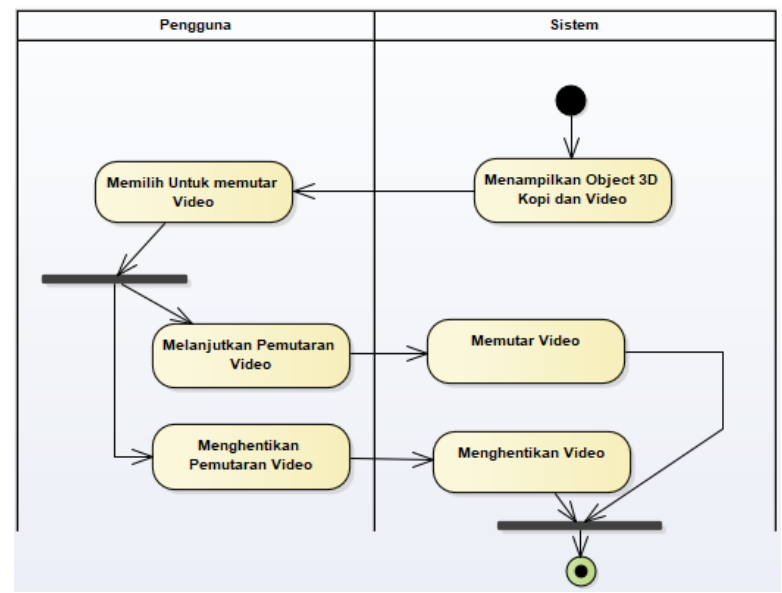

Gambar 5. Activity Diagram Memutar dan Menghentikan Video 
Pada Gambar 5 sistem menampilkan Objek 3D kopi dan video, pengguna dapat berinteraksi dengan video tersebut dan memiliki opsi untuk memutar video tersebut. Jika video tersebut diputar, maka sistem akan memutar video tersebut. Jika pengguna memilih untuk menghentikan video, maka sistem akan menghentikan pemutaran video tersebut.

\section{E. Sequence Diagram}

Sequance diagram merupakan salah satu diagram pada UML, diagram ini menjabarkan kolaborasi dinamis pada sejumlah objek dalam sistem. Sequance diagram mampu menunjukan detil proses dan pesan yang berinteraksi dengan objek dengan mewakili waktu yang berdasarkan garis horizontal. Langkah urutan proses terhadap objek - objek dapat juga terlihat pada Sequance diagram.

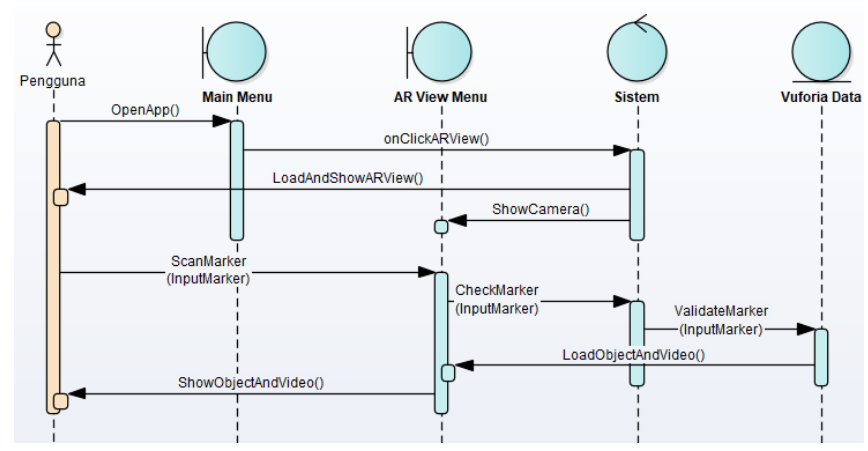

Gambar 6. Sequence Diagram Memilih AR View

Pada Gambar 6 menjelaskan pengguna dapat berinteraksi dengan sistem melalui berbagai proses. Proses penting disini adalah bagaimana sistem melakukan validasi terhadap marker yang sudah disiapkan oleh pengguna dan library Vuforia akan melakukan proses verifikasi terhadap marker tersebut. Jika marker tersebut terdapat pada data Vuforia, maka objek 3D dan video akan tampil pada marker tersebut.

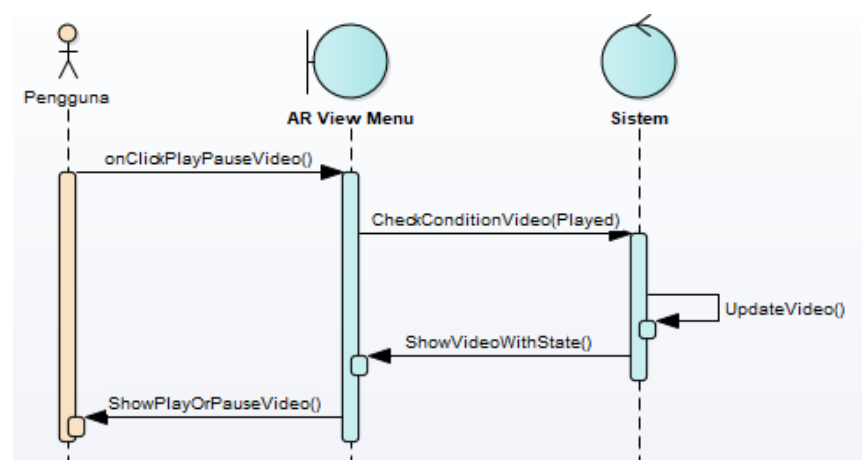

Gambar 7. Sequence Diagram Memutar dan Menghentikan Video

Sequance diagram memutar dan menghentikan video menjelaskan interkasi pengguna dengan sistem dimana jika pengguna ingin memutar video maka sistem akan memutar video tersebut. Jika pengguna ingin menghentikan pemutaran video, maka pengguna dapat menghentikan video dan sistem akan menghentikan video tersebut. Untuk memulai pengguna dapat berinteraksi dengan tombol putar, sedangkan untuk menghentikan penggunaka dapat beriteraksi dengan tombol henti yang sudah disediakan.

\section{F. Desain Arsitektural}

Pada bagian desain arsitektural ini akan dijabarkan tentang alur kerja secara global. Alur ini berisikan cara kerja sistem yang berinteraksi dengan pengguna. Terdapat beberapa entitas pada desain arsitektural seperti pengguna, objek yang digunakan, atau output yang dihasilkan oleh sistem. Desain arsitektural sistem ini dapat dilihat pada Gambar 8.

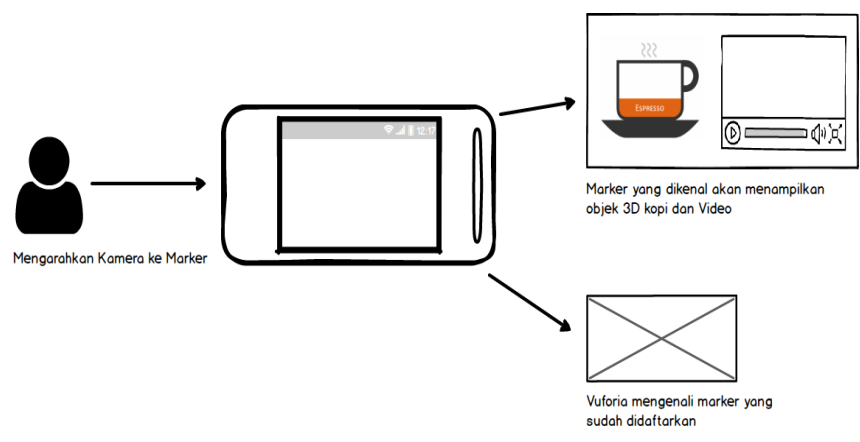

Gambar 8. Desain Arsitektural Aplikasi Coffee AR

Pada Gambar 8 dijelaskan bahwa pengguna akan menggunakan kamera yang sudah diaktifkan oleh Vuforia. Selanjutnya pengguna memindai marker yang sudah tersedia. Jika marker cocok dengan data pada data Vuforia, maka objek 3D dan video akan tampil pada layar mobile.

\section{G. Desain Prosedural}

Desain prosedural dibuat guna menunjukan detil alur algoritma pada sistem. Desain prosedural digunakan setelah membuat desain sistem, desain arsitektural, serta desain interface dari aplikasi.

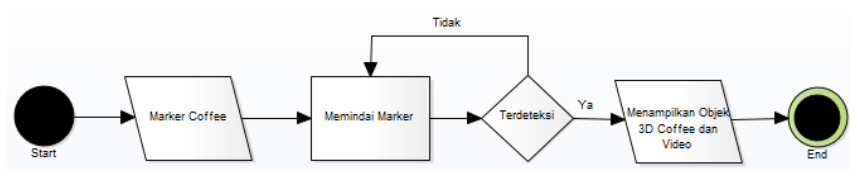

Gambar 9. Diagram Alir Proses Menampilkan Objek 3D dan Video

Pada Gambar 9 pengguna menyiapkan marker untuk dipindai dan sistem akan memindai marker dari pengguna. Jika marker terdeteksi pada data Vuforia, maka objek 3D dan video akan muncul di layar mobile.

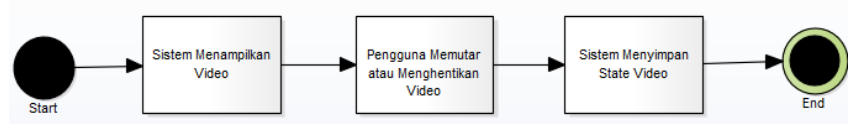

Gambar 10. Diagram Alir Proses Menambah Furnitur

Ketika sistem berhasil memindai marker, maka video akan muncul dilayar mobile. Pengguna dapat memutar atau menghentikan video yang muncul. 
H. Desain Antarmuka

Pada bagian ini dijabarkan desain antarmuka dari aplikasi Coffee AR. Terdapat 4 menu yaitu main menu, AR View menu, credit page menu, how to use app menu. Setiap menu dapat diakses oleh dan pengguna dapat berpindah menu dengan menggunakan tombol kembali untuk kembali ke menu sebelumnya.

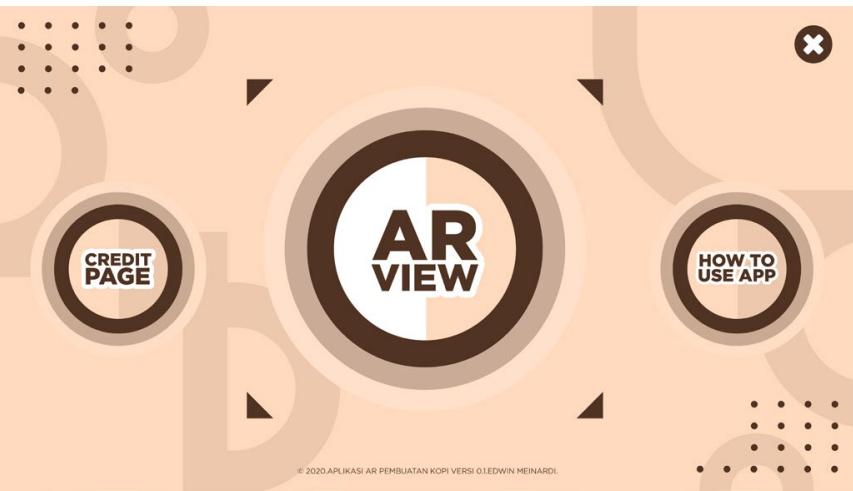

Gambar 11. Desain Main Menu

Gambar 11 Merupakan tampilan halaman utama dari aplikasi ini. Saat pengguna menjalan aplikasi, halaman main menu inilah yang pertama kali ditampilkan. Pada menu ini terdapat 3 tombol yang bisa diakses oleh pengguna, yaitu tombol Credit page, tombol AR View, dan tombol How to use app. Pengguna dapat menutup aplikasi ini dengan menekan tombol silang yang berada pada kanan atas.

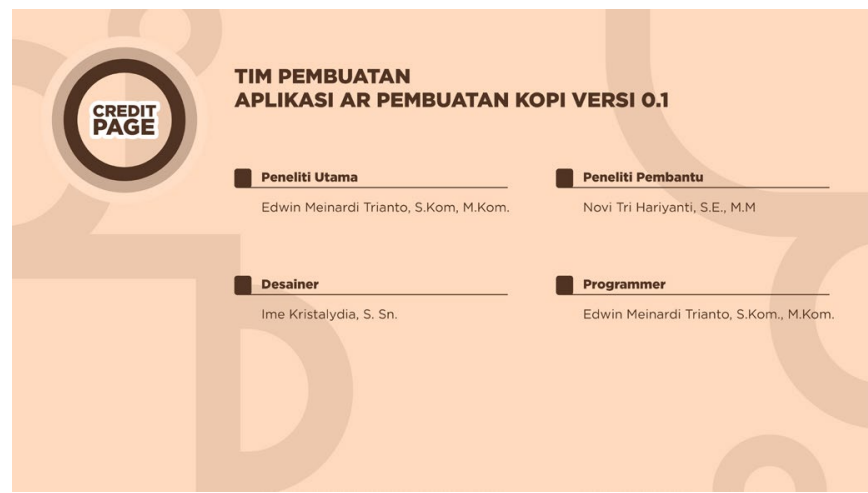

Gambar 12. Desain Credit Page Menu.

Gambar 12 Merupakan tampilan ketika pengguna menekan tombol Credit Page pada halaman awal. Menu ini menampilkan nama-nama yang berkontribusi dalam pembuatan aplikasi Coffee AR. Terdapat nama peneliti utama, peneliti pembantu, desainer untuk marker dan objek 3D minuman kopi, serta programmer.

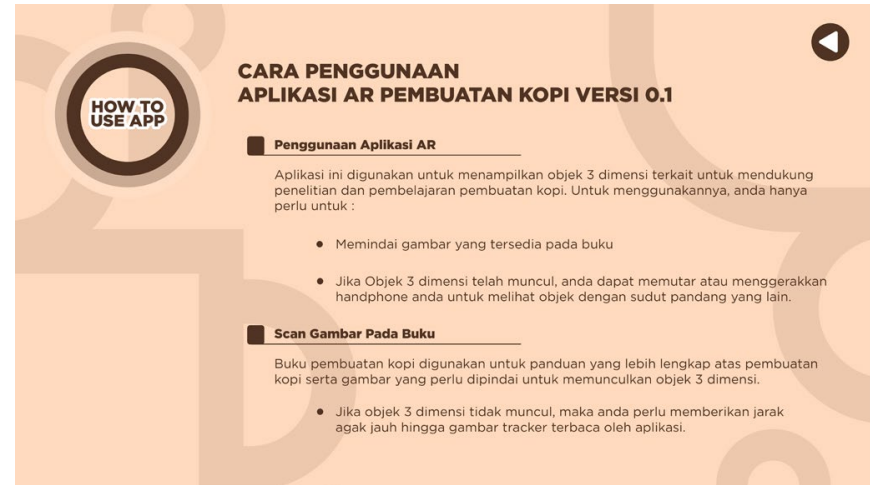

Gambar 13. Desain How To Use App Menu.

Saat pengguna menekan tombol How To Use App pada Main Menu maka pengguna diarahkan pada menu How To Use App. Menu ini menjelaskan ke pengguna bagaimana cara menggunakan aplikasi. Pengguna memerlukan marker yang terdaftar pada data Vuforia untuk proses pemindaian.

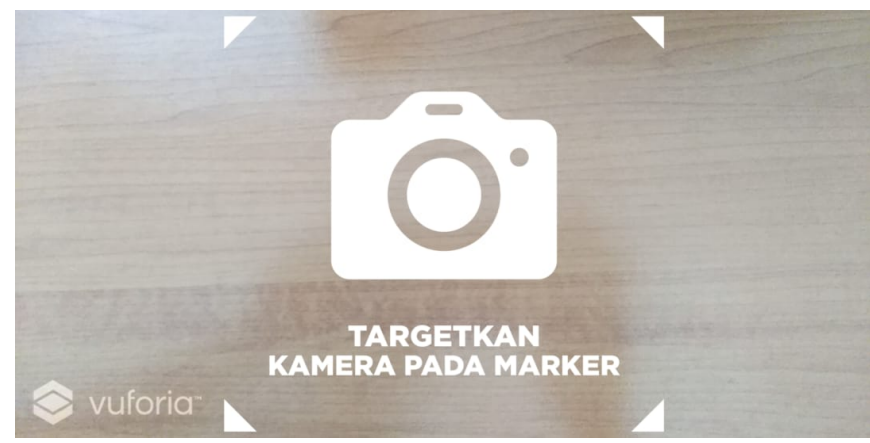

Gambar 14. Desain AR View Menu

Gambar 14 adalah Menu AR View dimana ketika menu ini dibuka, secara otomatis Vuforia akan mengaktifkan kamera pada smartphone. Jika kamera smartphone belum mendekteksi marker yang sesuai, maka akan menampilkan interface yang bertuliskan "Targetkan kamera pada marker". Ketika kamera sudah menemukan marker yang sesuai, maka interface tersebut akan hilang.

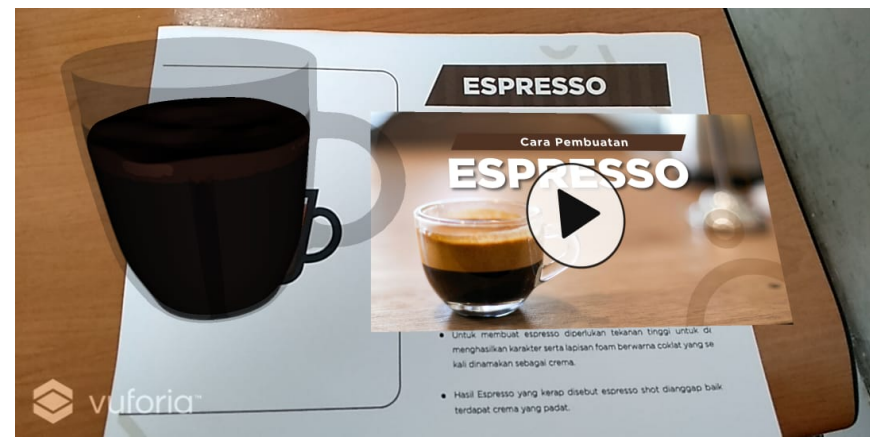

Gambar 15. AR View Menu dengan Marker

Gambar 15 Merupakan AR View Menu dengan kondisi kamera sudah menemukan marker yang sesuai. Ketika marker yang sudah didaftarkan pada Vuforia cocok, maka objek 3D kopi dan video akan muncul. Terdapat beberapa marker yang 
akan menghasilkan objek 3D dan video yang berbeda beda. Namun jika marker tidak sesuai atau marker tidak dipindai oleh pengguna, maka akan muncul Gambar 14 dimana pengguna perlu memindai ulang marker yang sesuai.

\section{Pengujian}

Proses uji coba yang diterapkan pada aplikasi Coffee AR ini menggunakan metode black box testing. Metode black box testing merupakan teknik pengujian dengan berfokus pada hasil output melalui beberapa proses data uji dari fitur yang telah dibuat. Proses ini dapat melihat fitur atau modul yang belum maksimal atau masih terdapat bug (kesalahan program). Selain menggunakan metode black box testing, uji coba ini juga menggunakan metode kuisioner. Kuisioner merupakan teknik pengumpulan data yang didapatkan dari pertanyaan yang diberikan oleh pengguna aplikasi Coffee AR. Dari metode ini bisa didapatkan masukan dan dapat menjawab apakah aplikasi ini dapat membantu pengguna yang belum mengetahui informasi-informasi seputar menu minuman kopi.

Hasil uji coba menggunakan metode black box testing mendapat kesimpulan bahwa semua skenario dan fitur yang terdapat pada aplikasi Coffee AR memberikan output yang baik. Aplikasi Coffee AR dapat menjalankan semua fungsi tombol pada setiap menu dengan baik. Fungsi kamera pada library Vuforia dapat diaktifkan dengan baik ketika masuk pada menu AR View. Kamera yang diaktifkan juga bisa membaca marker yang sudah didaftarkan pada Vuforia. Berdasarkan pengujian ini, dapat dilihat bahwa fungsionalitas aplikasi ini dapat berjalan dengan baik.

Hasil uji coba menggunakan metode kuisioner dengan penyebaran kuisioner ke 30 responden yang menggunakan aplikasi, dapat membuktikan bahwa aplikasi ini memberikan informasi yang baik terhadap pengguna. Aplikasi Coffee AR dinilai sangat mudah dalam penggunaannya sehingga informasi yang disediakan oleh aplikasi ini dapat tersampaikan dengan baik.

\section{KESIMPULAN DAN SARAN}

Berdasarkan proses hasil uji coba yang sudah dilakukan dapat diperoleh kesimpulan bahwa aplikasi Coffee AR yang dikembangkan dengan menggunakan Unity 3D dan library Vuforia engine dapat membuat aplikasi media interaktif augmented reality dengan baik. Hal ini dapat dilihat dari kinerja dan performa library Vuforia dalam pembuatan aplikasi augmented reality.

Objek 3D dan video yang muncul saat menggunakan marker yang tepat sudah dapat dilihat dengan baik dan menarik. Berdasarkan hasil kuisioner didapatkan kesimpulan bahwa aplikasi Coffee AR dapat memberikan informasi yang baik dan berguna. Hal ini didasari dengan sebanyak $80 \%$ responden mengatakan bahwa tampilan pada aplikasi ini sudah menarik dan mudah untuk digunakan. Sebanyak 83,3\% responden mengatakan bahwa aplikasi ini dapat memberikan informasi tentang menu minuman kopi dengan baik, serta sebanyak 73,3\% mengatakan dengan adanya video dapat membantu mereka memahami gambaran menu minuman kopi tersebut.

Setelah proses uji coba yang dilakukan, diperoleh beberapa saran untuk mengembangkan aplikasi ini lebih lanju seperti menambahkan lebih banyak varian menu minuman kopi, menambahkan proses animasi 3D bagaimana proses pembuatan minuman kopi, dan menambahkan informasi alatalat yang digunakan dalam pembuatan minuman kopi.

\section{UCAPAN TERIMA KASIH}

Dalam kesempatan ini peneliti memanjatkan rasa syukur yang besar kepada pihak yang telah membantu proses penelitian ini dengan baik. Peneliti juga mengucapkan terima kasih kepada Direktorat Riset dan Pengabdian Masyarakat, Deputi Bidang Penguatan Riset dan Pengembangan, Kementerian Riset dan Teknologi/Badan Riset dan Inovasi Nasional, Republik Indonesia yang telah memberikan dana Hibah Penelitian Dosen Pemula sesuai dengan Kontrak Penelitian Nomor 001/SP2H/LT/P3M/IKADO/III/2020 atas bantuan dana yang diperlukan untuk penyelesaian penelitian ini.

\section{REFERENSI}

[1] Mustaqim, I. (2016). Pemanfaatan Augmented Reality Sebagai Media Pembelajaran. Jurnal Pendidikan Teknologi Dan Kejuruan, Vol. 13(2), pp. 174-183. https://doi.org/10.23887/jptk.v13i2.8525

[2] Aguston, R.L., Andika, H. \& Trianto, E.M. (2017). Pemanfaatan Augmented Reality Pada Permainan Othello. Teknika, Vol. 5(1), pp. 1-9. https://doi.org/10.34148/teknika.v5i1.46

[3] Craig, A.B. (2013). Understanding Augmented Reality: Concept and Applications. America: Morgan Kaufmann

[4] Kaufmann, H. (2003). Collaborative Augmented Reality in Education. Education and Information Technologies.

[5] Moldvaer, A. (2014). Coffee Obsession: More Than 100 Tools and Techniques with Inspirational Projects to Make. DK Publishing

[6] Michelman, J. \& Carlsen, Z. (2018). The New Rules of Coffee: A Modern Guide for Everyone. Ten Speed Press.

[7] Morales, C. (2015). Developing Augmented Reality applications with Unity $3 D$ and Vuforia. Indiana: AcademicBooks.

[8] Okita, A. (2015). Learning C\# Programming with Unity $3 D$. New York: CRC Press.

[9] Kenneth, S. (2017). Data Analysis with IBM SPSS Statistics. Birmingham: Packt. 